Working Paper 97-30

Business Economics Series 05

April 1997
Departamento de Economía de la Empresa

Universidad Carlos III de Madrid

Calle Madrid, 126

28903 Getafe (Spain)

Fax (341) 624-9608

\title{
COMPETING THROUGH MARKETING ADOPTION: A COMPARATIVE STUDY OF INSURANCE COMPANIES IN BELGIUM AND SPAIN
}

\author{
Clara Eugenia García*; Victor Molero*" and Jaime Rivera Camino*
}

\begin{abstract}
This paper presents a diagnosis of the current development stage of insurance firms operating in Belgium and Spain according to the differential patterns they exhibit in the adoption of marketing concept. The theoretical approach we use here has been defined in order to include three critical dimensions: the organizational process that encompasses the marketing adoption concept; the extend to which differential marketing patterns are related to business and economic performance, and finally to identify the influence of managerial decision making and their planned patterns of strategic behavior in the development and ongoing process of marketing adoption. Finally departing from increasing globalization and competition our analysis has been extended to offer empirical evidence focusing on how national culture and market conditions might influence the organizational process shaping marketing adoption.
\end{abstract}

Key Words:

Insurance sector, services, marketing, organizational adoption, competition marketing.

"Universidad Carlos III de Madrid, Departamento de Economía de la Empresa, C/ Madrid, 126, 28903 Getafe (Madrid). Email: claragar@emp.uc3m.es y jrivera@emp.uc3m.es. 


\section{INTRODUCTION}

Recent analysis have pointed out that business services play a crucial role both in promoting investment, innovation and technological progress and in the adaptation of firms to changes in costumers'needs. More specifically it has been suggested that financial and insurance services represent the lubricants of the economy, and that they require special marketing treatment (Lovelock, 1981). In spite of the critical role played by the information properties of market and organizational structures managed by marketing for insurance companies the number of empirical studies available is very limited (Edgett and Thwaites, 1990).

Marketing for insurance companies becomes crucial since they operate in a market plagued of undesirable risks mainly related to opportunistic behavior and information asymmetries either ex ante (adverse selection) or ex post (moral hazard). Besides the incentive for the costumer to cheat here sales precede production of the service, and consequently the commercialization emerges as a promise that requires certain levels of trust in the service'seller (Lambin, 1993). Departing from the latter and according to Lambin the marketing perspective must involve all of the organization's members. Here information is a crucial requirement affecting economic performance; thus insurance companies are forced to efficiently manage marketing variables in order to achieve long-term success (Muth, 1993).

Altogether, insurance companies operating in Europe face now a more complex and unsettled environment: the level of competition within the sector increased greatly and forced single companies and insurance groups to restructure, customers' behavior has also evolved and clients are now more demanding in terms of services while the levels of loyalty have decreased. As a result, many authors affirm that because of changes in consumers'needs marketing strategies became an effective tool to increases survival probabilities in the new competitive environment.

The influence of cultural specificities upon the use of marketing variables emerge as crucial. Literature indicates that a nation's character and culture as well as political and economic variables might influence the way firms respond to their markets (Porter, 1990). Furthermore, culture also has an influence on the organizational behavior and management styles (Meindl, Hunt and Lee, 1989). Despite its theoretical relevance, however, there are few empirical studies that focus on the influence of country specificity concerning marketing adoption.

Thus, we shall analyze whether cultural differences, operationalized in the country variable $^{1}$, also influence the process of marketing concept adoption by Spanish and Belgium firms. According to Nuttney (1995), the Belgian market is among the most developed markets in Europe for personal insurance while, on the other hand, expected

1 Because of the difficulties in delimiting the amorphous concept of culture, the nations is used as a surrogate-albeit imperfect-for culture (Nakata and Sivakumar 1996) 
market growth is moderate. By the contrary Spanish market is among the "smallest" of Europe concerning personal insurance

Although Spain is a late comer and one of the latest in the regulations of EC affecting insurance. Deregulation and new competition policies have spurred the growth and development of the Spanish insurance market, which is now on its way to becoming one of the most dynamic in Europe. Spain's large population and the developing of financial services provide excellent prospects for future market growth (Nuttney, 1995).

Since marketing is very important to insurance firms (Greenwald, 1992), and little research has been done on the insurance sector, this paper is based on a theoretical model that identifies objectives and measurable criteria in order to evaluate the process of marketing adoption by insurance companies. Moreover this model also address a set of theoretical problems related to the adoption of marketing. Our analysis has three objectives. First, to explore the organizational process that allows firms to adopt differential marketing patterns. Second, to link this process with business performance, and third, to identify the impact of purposeful managerial behavior in the marketing adoption process.

The first part will introduce the theoretical model and set of propositions on the adoption of marketing. In the second part we present and discuss the main features and results. And, finally the conclusion contents a presentation of the managerial implications of our analysis.

\section{THE ADOPTION OF THE MARKETING CONCEPT}

Analysis of the adoption of the marketing concept have been conducted at the firm level within different services industries: building societies (Thwaites and Lynch, 1992), health care (Hampton, 1992), engineering consultancy (Morgan and Morgan, 1991), incoming tourism (Greenley and Matcham, 1990), law and accounting services (Morgan, 1990), general services (Hooley and Cowell, 1985), retailing (Piercy and Alexander 1988) and financial services (Piercy and Morgan, 1989). In most of these studies the marketing concept has been operationalized in different ways contributing to a general confusion as to what a marketing orientation means.

Further examination and redefinition of the traditional marketing concept has focused on country-specific changes (Grönroos 1989). Recently it has been suggested that marketing must broaden its role in the organization (Boyd and Walker, 1990; Morgan and Piercy, 1991, Webster, 1992) and that cross-country comparisons are needed (Thomas, 1994; Webster, 1994).

Today there is little doubt that marketing is itself a process (Ferrel and Lucas, 1987), that follows an evolutionary path progressing through different stages till it is completed with the adoption of marketing by the whole organization. However there is a great bulk of research emphasizing the adoption of marketing as result of environmental conditions 
(Kotler, 1988). It is our major claim that this models cannot address why, in the same time period, are there firms that use marketing systems and techniques that belong to different historical or evolutionary stages. Another common disadvantage of these models is that they do not present an operationalization of the different stages that compose the process being suggested. This is something which hinders the classification of the firms according to the marketing stage which they are developing.

The positive impact of the adoption of marketing on the firm's economic performance has been controversial and subject to major criticisms (Hayes and Abernathy, 1980; Bennett and Cooper, 1981) though recent empirical validations indicate a positive relationship between the adoption of marketing and the firm's performance. Nevertheless, these analysis take into account a limited set of variables related to the adoption of marketing like planning (Baker, Black and Hart, 1988), preferred market tactics (Speed and Smith, 1993) and the organization of the marketing department (Ghosh, Schoch, Taylor, Kwan, Kim, Teo, 1994). In this paper we account for the joint impact of any of those variables.

\section{MARKETING PATTERNS}

Recent marketing models emphasize the co-existence of different marketing stages (Lambin, 1993), incorporating the Production-Sales-Marketing model fully accepted by marketing scholars (McCarthy and Perreault, 1990). This model is based on the firm's strategic marketing goals in each stage and includes techniques and environments belonging to different historical stages. The model assumes that the adoption of marketing follows three evolutionary stages: passive marketing, organizatinal marketing and active marketing. They are differentiated by the organizational resources at use in each stage, the level of formalization of the marketing department, the scope of responsibilities allocated to it, and the type of competitive tactics developed.

We assumed that these components are independent dimensions and they are developed from the interplay between the organizational context and management decisions (Scott, Mitchell and Birnbaum, 1981). Moreover in this paper we assume that managers play a critical role in the adoption of marketing since they have policies as well as theories, and individual differences concerning theories, values and perceptions of the external world influence the firm's environmental analysis and strategies.

This general view leads us to formulate the following research propositions:

Pl Firms that compete and face complex and non-stationary environments exhibit a specific marketing design configuration formalized around a marketing department. Which is designed to acquire and process information sets from the organization and its markets, and to translate it into broader organizational actions concerning product innovation, pricing policies, commercial actions and communication. 
Thus,

- A firm should be found in a passive marketing stage if there is not a fully organized and structured marketing department, often it is incipient or reduced to organize distribution.

- The firm reach an organizatinal marketing stage if the marketing department is structured as a sales department or a commercial department.

- And finally the firm shall be in an active marketing stage if marketing functions are organized as a department or independent unit.

Secondy,

P.2 There is a link between the allocation of decision-making, the tasks organized under the marketing executive, and the strategic role played by those tasks within a particular organizational structure.

Thus,

- In a passive marketing stage the management of marketing variables (4Ps) is dispersed through different organizational departments and the marketing executive decisions and tasks will affect only sales policies and control mechanisms.

- In an organizational marketing variables management is shared by different departments, but policies concerning product characteristics and design are held by Production. Marketing personnel is responsible for advertising and promotion as well as marketing research.

- In an active marketing is also in charge of decision making concerning products and their relationship with pricing policies, consumers behavior, market characteristics, and financial constrains shaping the firm's activities.

Third,

P.3 Firms exhibit specific marketing tactics to match increasingly flexible customer expectations, and to capitalize on specific market opportunities.

Thus,

- In the passive marketing stage, marketing tactics do not take customer satisfaction into account but the needs of the company.

- In organizatinal marketing, marketing tactics are based on low levels of market segmentation.

- In the active marketing stage, tactics are guided by alertness to competition and environmental changes. Specific products are developed to satisfy well segmented necessities, and product innovation becomes a regular pattern of behavior. The firm bases its actions on clearly defined marketing plans.

With respect to the performance associated with the adoption of the marketing concept, there are several authors who indicate a positive relationship (Jaworski and Kholi, 1993; Hooley and Hoover, 1986; Hooley, Lynch and Shepherd, 1990). We have incorporated a system-structural perspective to analyze whether or not the structure of the marketing department can also generate high performance for the companies. Thus, taking into account all of this it follows the proposition: 
P.4. Any marketing configuration leads to reach a specific performance level, though an association between the performance of the firms and the organization of the marketing department exists. The level of responsibility that the marketing department has in regards to the organizational tasks concerning the market, the level of use of marketing research and tactics developed by the firms influence performance.

Finally, the operationalization based on this model permits us to analyze whether or not a coherence exists between the organizational design of the department, the set of tasks and decision-making allocated, and the tactics toward the markets. This analysis is based on the assumption that the purpose of organizational design is to provide conditions which facilitate one's optimal attainment of objectives and that this purpose guides the allocation and the use of organizational resources. Hence,

P.5. If marketing is the outcome of rational behavior it must exist coherence, between opportunity conditions, and tactics toward markets, cumulativeness or organizational design, and responsibilities -tasks-and levels of decision making allocated.

For our research, this intentionallity will be evaluated by the degree of positive association between the structural dimensions of the adoption process of the marketing that the companies have developed (Jauch Glueck, 1988; Walker and Ruekert, 1987).

\section{RESEARCH METHODOLOGY AND DATA}

\section{Methodology}

The research reported in this article is based on data taken from representative samples of insurance firms operating in Belgium and Spanish, and including life and non-life insurances. Data were collected using a mail questionnaire ${ }^{2}$ in order to test our propositions and to explore how insurance companies are adopting particular marketing concepts to adapt to changing environments. Alternative methods such as an interview or case study approach were deemed inappropriate. Finally firms of our sample have been categorized by the size of assets to control whether or not differences among firms are related to size.

\section{The sample}

Similar criteria of homogeneity were used in both countries; discarding records from branch companies lacking managerial autonomy as well as those companies with a market share inferior to $0.025 \%$ in Belgium and $0.05 \%$ in Spain.

In Belgium, 76 companies out of the 264 companies listed in the Office of Control of Insurances were selected as the target population. The level of response was of $45 \%$. In Spain, the sample was conformed by 100 companies departing from a total population

2. In Belgium the survey was taken between May 1994 and December 1994 while in Spain field work was done from June 1996 till December 1996. 
of 252 insurance firms belonging to 113 major groups. The level of response was here lower $(30 \%)$ though acceptable. The representativeness of the both samples, with respect to the total number of firms identified, was verified by the comparison of the frequency distributions. The $\mathrm{X}^{2}$ test indicates that meaningful differences to $5 \%$ do not exist between the frequency distribution of our sample and those of the target population (by using assets as criteria).

\section{The Questionnaire}

In order to enable the marketing tasks assigned to the chief marketing executive (CME) to be explored, the selection of responsibilities often associated with the marketing department were put forward. The respondents were asked to measure $\mathrm{CME}$ responsibility on a scale of "full and sole responsibility" (1), through to "no responsibility" (5). The items were generated through an inspection of the literature and refined after a discussion with managers and with marketing professors. This scale obtained a satisfactory reliability level $($ Belgium $=$ alpha cronbach .7504 ; Spain= alpha cronbach .7669).

The scale to evaluate the use of marketing research was built following a similar procedure. The questionnaire refers to the frequency of use on a scale of "never" (1) to "frequently" (5). The reliability level of this questionnaire was also satisfactory (Belgium= alpha cronbach .8275; Spain= alpha cronbach .8825).

Market tactics were generated from the theoretical proposals of Lambin's model, complemented with an inspection of the literature and verified through information provided by practitioners and scholars. This questionnaire obtained a satisfactory reliability level (Belgium= alpha cronbach .8487; Spain= alpha cronbach .8555 ). The questionnaire evaluated the degree to which these affirmations reflect the real operation of the company. The first scale was graded from 0 to 10 , in which 0 indicated that the firm did not develop that practice "in no degree", 5 indicated that it developed it "more or less" and 10 that it developed it to "an intensive degree". The second scale permitted the interviewee to state whether or not the proposal was pertinent to the reality of his firm.

Performance was measure in Belgium by collecting the information published by the insurance firms in Top Trends 5000 (1994) and in the Rapport of Office of Contrôle Assurances (1994). The 1993 Net Profits and Net Profits Growth (1991-1993) were used as economic performance criteria. The Gross Net Income Growth (1991-1993) and the 1993 Gross Net Income were used as market performance criteria. In Spain selected performance variables have been: sales growth as a proxy of effectiveness, New Product Launch Success Rate (NPLSR) as a proxy of adaptativeness, while efficiency was measured by Returns on Investments (ROI). In this country, interviewees were asked also to rank the position of their firms in comparison to major competitors and companies within the industry. 


\section{RESULTS}

The organization of the marketing department

This part deals with the level of formal organization acquired by the marketing department within insurance companies. The results of the inquiry (Table 2) indicate that insurance firms in both countries have at least a formal representative in charge of marketing though the formalization of marketing around a specific department is not dominant. Marketing organization accounts for the majority of the firms more than 2 FTP (Table 3). This data confirms that the adoption of the marketing concept in service organizations does not necessarily require a formal department, but a coordinator who organizes the marketing actions taken by the organization (Grönroos, 1980).

Insert Table 2 about here

Insert Table 3 about here

Although meaningful differences do not exist between firm's size and the organization of marketing functions around a specific department it is worthnoticing that SMEs (Small and Medium Enterprises) significatively differ with respect to the number of full time marketing employees in both countries.

For the companies that have marketing departments it was found that in most of the cases these departments have been founded more than 4 years ago (Table 4).

Insert Table 4 about here

According to the marketing reporting level, taken as a proxy of the status and autonomy of marketing officers, the results (Table 5) obtained lead us to consider that organizatinal marketing is the dominant stage or pattern exhibit by insurance companies both in Belgium (56\%) and in Spain (65\%) while firms found in active marketing patterns are significatively higher in Belgium (32\%) than in Spain (21\%). 
Insert Table 5 about here

According to these results the first proposition established in this paper cannot be refuted since in spite of major transformations and increasing complexity of the technical environment within which insurance firms compete, they have not yet adopted an active marketing concept or pattern.

\section{The responsibilities and tasks}

Taking into account the assumption that the main task and objective of the marketing department is the management of the set of marketing variables (Gummesson, 1984), in this section, we analyze the assignments of this department within the firm. Here we extend our analysis to marketing concept adoption by focusing on the specific organizational tasks controlled by the marketing manager.

First of all, the t-test indicates that by company size meaningful differences of $5 \%$ do not exist according to the responsibilities assigned to the marketing department and the use of marketing research. Data from both countries ${ }^{3}$, indicate that insurance firms follow similar patterns on assignments and use of marketing research.

Secondly, in both countries firms are found in an organizatinal marketing stage. The fact that firms whose sales tasks are included under control of management of marketing are few supports this affirmation. Moreover, Table 6 indicates that in Belgium the marketing department is responsible for marketing research (56\%) and for advertising $(53 \%)$, and to a lesser degree $(32 \%)$ is in charge of public-relations. Product policiesmainly innovation- and pricing policies are out of the marketing domain. Firms in Spain follow a similar pattern though here the scope of marketing tasks is even more limited since a great number of firms share with other departments decision making concerning marketing variables. Marketing department decisions are mainly related to advertising $(30 \%)$, promotional campaigns (30\%), and marketing research $(27 \%)$.

Likewise, in both countries the number of firms that grant responsibilities and allocate decision making concerning to strategic planning to marketing are very few (23\% and

\footnotetext{
$3 \quad$ Marketing tasks: $\quad \mathrm{B}=3.21$, Std Dev 0.645; $S P=3.37$, Std Dev 0.610

Marketing research: $\quad \mathrm{B}=2.51$, Std Dev 0.744; $S P=2.50$, Std Dev 0.798
} 
$17 \%$ respectively) which is a clear characteristic of a passive marketing stage. Thus the common characteristic of insurance firms either operating in Belgium and Spain is that they are reactive instead of pro-active, and strategic planning receives little input from marketing departments (Edgett and Thwaites, 1990).

Insert Table 6 about here

According to Lambin's model, the process by which the organization is adapted to its environment is based on the use of strategic marketing and it comes from the analysis of the market. Taking into account this relationship, in this section we have focused on the resources the company provides to the marketing department to support the tasks allocated to it.

In the previous analysis, we found that the marketing department, in both countries, was mainly responsible for communication (advertising and promotion) and market research. However, this must be contrasted with the high number of companies that rarely use advertising pre-tests and analysis of advertising efficiency (Table 7).

While in Belgium the tasks of marketing research, identified in the previous analysis, are mainly directed toward the study of the distributors (61\%) and of the competitors $(53 \%)$, and they are developed within the firm (Table 7); in Spain marketing research concerns market share (24\%).

Here it is worth noticing that insurance companies do not grant a great relevance to the analysis of motivations and purchase behavior of consumers, and consequently some marketing decisions are not supported in terms of marketing information. Therefore, companies do not continue the analysis-action relationship established by strategic marketing. This affirmation is also supported by the low analysis of the environment that both Belgian and Spanish companies develop and that plays a crucial role for strategy selection (Hooley and Saunders, 1993).

Insert Table 7 about here 


\section{Marketing tactics}

This section attempts to analyze the actions that the firms realize to satisfy their markets and to face competitors. It is assumed that such set of actions will be the result of the marketing adoption by companies, and that they are related to particular marketing adoption stages. Empirical evidence shows that there are not meaningful differences between firms operating in Belgium and those operating in Spain $(B=5.59$, Std Dev 1.41; $S P=5.34$, Std Dev 1.41). If we assume that higher levels of marketing tactics are related to higher marketing adoption stages it seems clear that insurance companies are found still in an organizatinal marketing level.

According to our theoretical model we assumed that different marketing tactics belonging to different marketing stages may co-exist within business organizations. This is clearly indicated by the empirical data provided here since firms implement different tactics corresponding to different marketing stages according to the segment of the market they address.

Table 8 shows that Belgian insurance firms do not have on average interest in evaluating the satisfaction of their end markets, hence adopting a clear passive marketing pattern (63\%) while Spanish firms placed themselves within active marketing according to tactics toward the final client. Similar differential patterns are also found when taking into account tactics toward distributor mainly concerning the analysis of the level of satisfaction and flexible adaptation of products to perceived needs.

Considering that firms in order to be classified in an active marketing stage should base their marketing tactics on alertness of what major competitors do and how they behave as well as on the dynamics of external business environment, substantial differences between Belgium and Spain emerged. First, in Spain the number of firms found in a passive marketing is lower than in Belgium, and though majority of firms exhibit an organizatinal marketing pattern, the number of active marketing firms is relatively higher. Such differences might be explained as result of recent competition in the market as well as by major difficulties for expanding their markets.

Concerning the actions toward new product development for well segmented needs (characteristic of active marketing) similar differences persist, and while in Belgium only $31 \%$ are classified in the active marketing stage, in Spain they represent $64 \%$. However, major surprising differences are found when we refer to product innovation (Table 8: 4).

Insert Table 8 about here 


\section{The adoption of marketing and performance}

In this section, we will analyze whether or not a relationship exists between the organizational components of the adoption of the marketing concept and the set of economic and market performance criteria. An attempt will be make to evaluate whether or not the adoption of a superior marketing stage is translated into greater performance and to identify the specific variables positively associated to it.

As shown in Table 9 results from Belgian insurance firms confirm that there is a positive association between the amount of resources allocated to the marketing department (e.g. number of employees) and performance indicators either short-term (GPI 93 and NP 93) and long-term (GPI Growth and NP Growth).

Insert Table 9 about here

The specialization, or the organization of marketing in a formal department, is found to be associated with short term indicators (GPI 93). However, the number of years since the marketing department was founded, which would indicate the learning curve and organizational experience related to management and information about market and organizational variables, was found not to be associated with any indicator of performance ${ }^{4}$.

The level of control over the marketing tasks was found to be associated only with the indicators of short term performance. However, the level of use of marketing research was found to be associated with indicators of the short and long terms in economic performance and market performance. Market specific tactics have also been found to be associated with market indicators in the short term (Premium Income 93), but not for the growth in premium income in the long term. Marketing tactics are less associated with economic indicators in the short $\left(.2986^{*}\right)$ and long terms $\left(.3006^{*}\right)$.

Empirical evidence from Spanish insurance companies reveals (Table 10) also a positive relationship between organizational variables (number of employees and specialization) and the ROI.

\footnotetext{
These results require greater study since these contradict the benefits of the organizational learning. As a possible explication, we could suppose that our knowledge about markets is highly changing, difficult to standardize and difficult to formalize. As a consequence, the nature of the market knowledge is implicit and is more associated with the individual than with the organization.
} 
Insert Table 10 about here

The positive association between specialization and business performance has to be related to learning cumulative effects, though the number of years since the founding of the marketing department, also a proxy of the learning curve, seems to partially contradict the relevance of such effect. Such contradictory results might be indicating that while specialization and knowledge is an individual characteristic, Spanish insurance firms are failing in the conversion from individual skills into broader organizational knowledge.

Specific marketing tasks are only related to ROI, while marketing studies influence ROI and NPLSR but not SALES. These results evidence that accurate information about the market leads to customer satisfaction and great performance though it is also indicating that in Spain market information does not influence salesman actions, reinforced by the fact that the Marketing Department does not have direct control on selection and training of salesman.

Finally marketing tactics exhibit also a positive relationship with performance indicators (ROI and SALES) but the null association found between tactics and NPLSR is strongly related to the low level of product innovation (Table 8:4).

These results suggest that insurance firms'performance, both in Belgium and Spain, is not only associated with competitive tactics but more precisely with the specific organization of the marketing department and the resources allocated (personal and market information processed and gathered). The positive relationship between the marketing studies and performance confirms the theoretical proposals that suggest that these are the basis for business success.

\section{Marketing adoption process and purposeful behavior}

Here we analyze whether or not marketing adoption comes out of a purposeful organizational action by focusing on the degree of association between structural dimensions and marketing tactics.

Both in Belgium and Spain there is a null relationship between the level of interest of the companies for formally organizing the marketing department (specialization) and the 
level of power that is granted in order to control the marketing tasks. This result suggests the weak tendency to recognize the formal importance 5 of the marketing department (see Table 11).

Insert Table 11 about here

However while insurance firms operating in Belgium exhibit a weak association between marketing department's specialization and the level of use of marketing research $\left(.3320^{*}\right)$, in the case of Spain such relationship is null. Those differences confirm low level of consciousness about the advantages and benefits of market information gathered and processed by the marketing department; and for the Spanish firms it is a clear indicator of the lack of recognition that such specific knowledge that has to be produced and accumulated by a specific organizational unit.

The null association between years of marketing operations, the degree of power recognized to marketing and marketing tactics also indicate the lack of relationship between organizational design and allocation of resources, and consequently a low premeditation in the adoption of marketing, as well as a low degree of consciousness and intentionallity concerning marketing tactics design. Here it is assumed that the intentional adoption of marketing would have to be reflected in a greater association between the specialization, the marketing research and the tactics, since specialization leads to a better analysis of the market, and this is the raw material of successful marketing tactics (Cravens, 1987). Also, this null association shows that within the insurance industry departmental experience does not influences the choice of organizational strategies no that the greater experience in marketing will lead to a greater concern for adapting particular organizational actions to market conditions (Miles and Snow, 1978).

Marketing department'size is not related with tasks assigned. This implies that a logical relationship in the allocation of resources does not exist. It shows that the number of persons scarcely predicts the level of formal power of the marketing department. In both samples marketing personnel is in charge of marketing research since in house information analysis is required for market prospect, sales forecasts, and competitors analysis.

Likewise, another lack of coherence is found in the null association between the responsibility level of marketing tasks and the level of use of the marketing research.

This is confirmed when we see that the variable Price and the variable Product are still not responsibilities of the marketing department and that this rarely participates in strategic planning (data shown in table 6). 
According to Table 6, the Spanish insurance sector not consider that the marketing research is fully responsibility of marketing department.

Summarizing, our results suggest that Belgian and Spanish insurance firms exhibit a "laissez-faire" attitude towards marketing and that marketing adoption is hardly understood by calling attention on purposeful organizational actions. A similar phenomenon has been reported by Hooley, Lynch and Shepherd (1990) about English firms and by Gallucci and Rivera (1997) for a cross-section analysis of Spanish firms.

\section{CONCLUSIONS}

This study has confirmed the set propositions formulated about the organizational variables related to the adoption of marketing. The results show that the adoption of marketing is a multidimensional process which does not exclude the co-existence within a firm of organizational structures and tactics belonging to different marketing stages, contradicting the deterministic models that evaluate the adoption of marketing neglecting its organizational dimensions. In spite of some significative differences concerning specific marketing variables, on average, firms within the insurance industry in Belgium and Spain are found in an organizatinal marketing stage.

It is also found that insurance firms in both countries exhibit a common tendency to maintain and increase marketing use, as well as agree to the necessity of extending the marketing concept to include other publics in addition to the final user -distributor, environment and competition-.

Although agreement exists among the interviewed firms as to the consideration of marketing as an accepted formal managerial department but it does not imply that it is the result of a conscious and purposeful organizational action.

Not all of the marketing tactics are performed at the same level, although the importance granted to the distributors is emphasized. This result is coherent with the recommendations formulated for the insurance firms for their successful adaptation to a new competitive environment. The tactics developed more regularly are related to the coordination of the organizational actions directed to the market. These results confirm the high level of coordination necessary for the unstructured tasks, like those of the services.

Empirical data collected both in Belgium and Spain provide strong evidence about the limited impact of the Chief Marketing Executive in pricing and product development policies, and the major tasks and marketing functions allocated in to the marketing department are those related to advertising and promotion. Moreover the use of information sets gathered by the marketing department was found to be limited within the hierarchy. 
The results also show that a positive association exists between marketing stages and different short and long term performance indicators, which confirms that business performance depends as much on organizational components as on marketing tactics.

\section{FURTHER RESEARCH IMPLICATIONS}

Further research on the insurance services' marketing is obviously necessary and this exploratory research has attempted to establish some foundation for future studies. One of the relevant areas for future research constitutes the complex organizational process and cognitive problems that are likely to block the adoption of active marketing patterns. It is convenient to study why in spite of the theoretical importance of the marketing department, it still doesn't have the responsibility of the marketing tasks, nor does it participate in strategic planning.

Another area of study is related to the use of organizatinal marketing knowledge. Future research should analyze how to generate, store and use the experience of the market to increase the competitiveness of the firm. Within this area, how to use the market research to support the tasks of the marketing department and the competitive market tactics should be investigated.

The relationship between business performance and the delivery system of the services should also be investigated. This would be an analysis of the delivery systems which correspond to the different evolutionary stages, the organizational components that intervene with them and their impact on business performance.

The topic of premeditation or coherence between the design and the adoption process of marketing is another topic which deserves further research. Hopefully, a better operationalization of the stages will facilitate the identification of controllable variables that will provide a planned adoption of the marketing concept for managers. 
TABLE 2. Organization of the Marketing Department

\begin{tabular}{|l|l|l|l|l|l|l|l|l|}
\hline $\begin{array}{l}\text { RESPONDENT } \\
\text { SIZE }\end{array}$ & \multicolumn{2}{|c|}{ ONE } & \multicolumn{2}{c|}{ ONE PERSON } & \multicolumn{2}{c|}{$\begin{array}{l}\text { DEPARTMENT IN } \\
\text { PEPARTMENT }\end{array}$} & \multicolumn{2}{|l|}{$\begin{array}{l}\text { NONE OF THE } \\
\text { PREVIOUS }\end{array}$} \\
\hline & BELGIUM & SPAIN & BELGIUM & SPAIN & BELGIUM & SPAIN & BELGIUM & SPAIN \\
\hline SMALL & 3 & 5 & 5 & 4 & 0 & 0 & 2 & 3 \\
\hline MEDIUM & 4 & 4 & 4 & 2 & 1 & 0 & 1 & 0 \\
\hline LARGE & 11 & 10 & 3 & 2 & 0 & 0 & 0 & 0 \\
\hline ALL $(\mathrm{n})$ & 18 & 19 & 12 & 8 & 1 & 0 & 3 & 3 \\
\hline \multicolumn{1}{|c|}{$(\%)$} & $(53 \%)$ & $63 \%$ & $(35 \%)$ & $27 \%$ & $(3 \%)$ & -- & $(9 \%)$ & $10 \%$ \\
\hline
\end{tabular}

TABLE 3. Number of Marketing Full Time Personnel

\begin{tabular}{|l|l|l|l|l|l|l|l|l|}
\hline & \multicolumn{7}{|c|}{ Number of Employees } \\
\hline $\begin{array}{l}\text { RESPONDENT } \\
\text { SIZE }\end{array}$ & \multicolumn{2}{|c|}{$1(\mathrm{n})$} & \multicolumn{2}{c|}{$2(\mathrm{n})$} & \multicolumn{2}{c|}{$3(\mathrm{n})$} & \multicolumn{2}{c|}{4 or more (n) } \\
\hline & BELGIUM & SPAIN & BELGIUM & SPAIN & BELGIUM & SPAIN & BELGIUM & SPAIN \\
\hline SMALL & 5 & 1 & 2 & 1 & 1 & 1 & 1 & 0 \\
\hline MEDIUM & 4 & 2 & 3 & 1 & 1 & 3 & 0 & 1 \\
\hline LARGE & 3 & 2 & 1 & 4 & 2 & 4 & 8 & 6 \\
\hline ALL (n) & 12 & 5 & 6 & 6 & 4 & 8 & 9 & 8 \\
\hline
\end{tabular}

TABLE 4. Number of years since Marketing Department was founded

\begin{tabular}{|l|l|l|l|l|l|l|l|l|}
\hline $\begin{array}{l}\text { RESPONDENT } \\
\text { SIZE }\end{array}$ & \multicolumn{2}{l}{ <2 YEARS } & \multicolumn{2}{l|}{ 4-5 YEARS } & \multicolumn{2}{l|}{$>$ Y YEARS } \\
\hline & BELGIUM & SPAIN & BELGIUM & SPAIN & BELGIUM & SPAIN & BELGIUM & SPAIN \\
\hline SMALL & 2 & 3 & 0 & 4 & 4 & 2 & 2 & 3 \\
\hline MEDIUM & 3 & 1 & 2 & 1 & 2 & 3 & 3 & 2 \\
\hline LARGE & 1 & 0 & 2 & 1 & 3 & 3 & 7 & 4 \\
\hline ALL & 6 & 4 & 4 & 6 & 9 & 8 & 12 & 9 \\
\hline
\end{tabular}

TABLE 5. Marketing Reporting Level

\begin{tabular}{|l|c|c|}
\hline CME reports to & $\begin{array}{c}\text { BELGIUM } \\
(\%)\end{array}$ & $\begin{array}{c}\text { SPAIN } \\
(\%)\end{array}$ \\
\hline $\begin{array}{l}\text { - Senior management/ } \\
\text { Executive committee }\end{array}$ & $32 \%$ & $21 \%$ \\
- $\begin{array}{l}\text { Managing partner/ } \\
\text { chief executive }\end{array}$ & $56 \%$ & $65 \%$ \\
- Others & $12 \%$ & $14 \%$ \\
\hline
\end{tabular}


TABLE 6. The Responsibility of the Marketing Department

\begin{tabular}{|c|c|c|c|c|}
\hline \multirow[b]{2}{*}{ Marketing task: } & \multicolumn{2}{|c|}{$\begin{array}{c}\text { Total formal } \\
\text { responsibility } \\
\%\end{array}$} & \multicolumn{2}{|c|}{$\begin{array}{l}\text { Average (mean) } \\
\text { responsibility } \\
\text { Score }\end{array}$} \\
\hline & BELGIUM & SPAIN & BELGIUM & SPAIN \\
\hline - Selection of personal of sale and of marketing & 20 & 15 & 2.64 & 3.53 \\
\hline - Management of sellers net and/or resellers & 17 & 12 & 2.10 & 2.76 \\
\hline - Advertising & 53 & 30 & 3.91 & 3.94 \\
\hline - Promotional campaigns & 50 & 30 & 3.87 & 3.94 \\
\hline - Marketing planning & 53 & 24 & 3.91 & 3.76 \\
\hline - Market research & 56 & 27 & 3.91 & 4.00 \\
\hline - Public relations & 32 & 21 & 3.26 & 3.52 \\
\hline - Commercial training & 12 & 18 & 2.43 & 3.29 \\
\hline - Development of concepts for new services & 32 & 12 & 3.41 & 3.17 \\
\hline - Strategic planning & 23 & 17 & 2.83 & 3.05 \\
\hline - Pricing policy and tariffs & 15 & 9 & 2.74 & 2.29 \\
\hline
\end{tabular}

\section{TABLE 7. Use of Marketing Research}

\begin{tabular}{|l|c|c|}
\hline & \multicolumn{2}{|c|}{$\begin{array}{c}\text { Frequency of use } \\
\text { Sometimes }\end{array}$} \\
\cline { 2 - 3 } Types of marketing research: & $\begin{array}{c}\text { BELGIUM } \\
\%\end{array}$ & $\begin{array}{c}\text { SPAIN } \\
\%\end{array}$ \\
\hline Quantitative measurement of market & 29 & 12 \\
Analysis of market share & 38 & 24 \\
Analysis of environment & 12 & 12 \\
Analysis of consumer's behavior & 20 & 6 \\
Analysis of buyer's motivations & 20 & 6 \\
Analysis of distribution channels & 61 & 15 \\
Analysis of competition & 53 & 18 \\
Advertising pre-tests & 3 & 6 \\
Analysis of advertising efficiency & 14 & 9 \\
Study of price elasticity & 3 & 6 \\
Quantitative sale forecasts & 67 & 18 \\
Quantitative analysis of product-market trend & 26 & 15 \\
Testing of new product concepts & 17 & 3 \\
& & \\
\hline
\end{tabular}

\begin{tabular}{|c|c|c|c|}
\hline \multicolumn{2}{|c|}{$\begin{array}{c}\text { Internal Service } \\
\%\end{array}$} & \multicolumn{2}{|c|}{$\begin{array}{c}\text { External Service } \\
\%\end{array}$} \\
\hline B & S & B & S \\
& & & \\
\hline 44 & 39 & 17 & 50 \\
47 & 45 & 23 & 41 \\
26 & 59 & 5 & 29 \\
23 & 29 & 26 & 54 \\
26 & 16 & 29 & 67 \\
73 & 24 & 8 & 61 \\
76 & 46 & 8 & 38 \\
11 & 23 & 14 & 26 \\
11 & 23 & 29 & 30 \\
11 & 20 & 3 & 16 \\
73 & 63 & 5 & 3 \\
53 & 50 & 3 & 33 \\
38 & 10 & 8 & 16 \\
& & & \\
\hline
\end{tabular}


TABLE 8 The Marketing Tactics

\begin{tabular}{|c|c|c|c|c|c|c|c|c|c|c|}
\hline \multirow{3}{*}{ The Marketing Tactics } & \multicolumn{6}{|c|}{$\%$ DE SCORES } & \multirow{2}{*}{\multicolumn{2}{|c|}{\begin{tabular}{|l} 
MEAN \\
SCORES
\end{tabular}}} & \multirow{2}{*}{\multicolumn{2}{|c|}{ STD DEV }} \\
\hline & \multicolumn{2}{|c|}{$1-4$} & \multicolumn{2}{|c|}{$\begin{array}{l}\text { Scale } \\
5-7\end{array}$} & \multicolumn{2}{|c|}{$8-10$} & & & & \\
\hline & $\mathrm{B}$ & $\mathrm{S}$ & $\mathrm{B}$ & $\mathrm{S}$ & $\mathrm{B}$ & $\mathrm{S}$ & $\mathrm{B}$ & $\mathrm{S}$ & $\mathrm{B}$ & $\mathrm{S}$ \\
\hline FINAL CLIENT & & & & & & & & & & \\
\hline 1. Analyze level of satisfaction & 63 & 17 & 26 & 23 & 11 & 58 & 3.71 & 5.9 & 2.53 & 2.48 \\
\hline 2. Analyze segments' appearance & 38 & 17 & 45 & 35 & 17 & 47 & 5.01 & 5.5 & 2.61 & 2.39 \\
\hline 3. Segments' solutions & 17 & 11 & 52 & 23 & 31 & 64 & 6.30 & 6.5 & 2.22 & 2.37 \\
\hline $\begin{array}{l}\text { 4. Commercialization new products } \\
\text { DISTRIBUTORS }\end{array}$ & 10 & 23 & 38 & 47 & 52 & 29 & 7.18 & 4.7 & 2.25 & 3.05 \\
\hline 5. Analyze level of satisfaction & 23 & 35 & 51 & 23 & 26 & 41 & 5.81 & 4.6 & 2.75 & 3.16 \\
\hline 6. Analyze necessities & 40 & 35 & 40 & 41 & 20 & 23 & 4.90 & 4.4 & 2.69 & 3.10 \\
\hline 7. Take into account his opinion & 14 & 23 & 35 & 35 & 51 & 41 & 6.75 & 5.1 & 2.36 & 3.18 \\
\hline $\begin{array}{l}\text { 8. Adapt products to necessities } \\
\text { COMPETITORS }\end{array}$ & 27 & 53 & 51 & 23 & 22 & 22 & 5.73 & 3.5 & 2.18 & 3.08 \\
\hline 9. Analysis of their strategy & 16 & 6 & 55 & 58 & 29 & 35 & 6.32 & 5.7 & 1.88 & 1.82 \\
\hline 10. Analysis of marketing policy & 61 & 17 & 31 & 41 & 8 & 41 & 3.58 & 5.5 & 2.57 & 2.50 \\
\hline 11. Act to protect the final client & 21 & 00 & 43 & 53 & 36 & 47 & 6.11 & 6.5 & 2.39 & 1.97 \\
\hline 12. Act to protect distributors & 21 & 17 & 34 & 41 & 45 & 41 & 6.28 & 5.5 & 2.64 & 2.74 \\
\hline $\begin{array}{l}\text { ENVIRONMENT } \\
\text { 13. Analyze changes final client }\end{array}$ & 41 & 11 & 28 & 41 & 31 & 47 & 5.50 & 5.8 & 2.70 & 2.00 \\
\hline 14. Analyze changes distributor & 38 & 23 & 32 & 47 & 30 & 29 & 5.60 & 4.7 & 2.59 & 2.53 \\
\hline 15. Influencing pressure groups & 48 & 30 & 36 & 47 & 16 & 23 & 4.37 & 4.5 & 2.80 & 2.29 \\
\hline 16. Act to show social utility & 38 & 11 & 41 & 47 & 21 & 41 & 5.07 & 5.6 & 2.96 & 2.31 \\
\hline COORDINATION & & & & & & & & & & \\
\hline 17. Elaboration of tactics & 15 & 23 & 35 & 35 & 50 & 41 & 6.67 & 5.6 & 2.20 & 2.39 \\
\hline 18. Marketing plan & 26 & 35 & 38 & 29 & 36 & 35 & 6.05 & 4.7 & 2.58 & 3.09 \\
\hline 19. Market commitment & 27 & 23 & 42 & 29 & 31 & 47 & 5.90 & 5.9 & 2.38 & 3.13 \\
\hline 20. Market-based information & 20 & 23 & 44 & 23 & 36 & 52 & 6.20 & 5.8 & 1.93 & 2.53 \\
\hline
\end{tabular}

TABLE 9 Association between Organizational Components and PerformanceBelgium

\begin{tabular}{|c|c|c|c|c|}
\hline \multirow{2}{*}{ Organizational Components } & \multicolumn{2}{|c|}{ Premium Income } & \multicolumn{2}{|c|}{ Net Profits } \\
\hline & GPI 93 & GPI Growth & NP 93 & NP Growth \\
\hline $\begin{array}{l}\text { ORGANIZATION } \\
\text {.Number of workers } \\
\text {.Specialization } \\
\text {.Years of departmenting }\end{array}$ & $\begin{array}{l}.6128 * * * \\
.3106^{*} \\
\mathrm{~ns} \\
\end{array}$ & $\begin{array}{l}.6118^{* * *} \\
\text { ns } \\
\text { ns } \\
\end{array}$ & $\begin{array}{l}.5896^{*} \\
\mathrm{~ns} \\
\mathrm{~ns}\end{array}$ & $\begin{array}{l}.4851^{*} \\
\mathrm{~ns} \\
\mathrm{~ns} \\
\end{array}$ \\
\hline $\begin{array}{l}\text { RESPONSIBILITIES } \\
\text {.Marketing tasks } \\
\text {.Marketing research }\end{array}$ & $\begin{array}{l}.3441^{*} \\
.3579^{*}\end{array}$ & $\begin{array}{l}\text { ns } \\
.3899\end{array}$ & $\begin{array}{l}\text { ns } \\
.5246^{* *}\end{array}$ & $\begin{array}{l}\text { ns } \\
.5993 * *\end{array}$ \\
\hline $\begin{array}{l}\text { TACTICS } \\
\text {.Tactics }\end{array}$ & $.3790 *$ & ns & $.2986 *$ & $.3006^{*}$ \\
\hline
\end{tabular}


TABLE 10 Association between Organizational Components and PerformanceSpain

\begin{tabular}{|c|c|c|c|}
\hline Organizational Components & ROI & NPLSR & SALES \\
\hline $\begin{array}{l}\text { ORGANIZATION } \\
\text {.Number of workers } \\
\text {.Specialization } \\
\text {.Years of departmenting } \\
\end{array}$ & $\begin{array}{l}.2806^{*} \\
.4230^{*} \\
\mathrm{~ns}\end{array}$ & \begin{tabular}{|l|} 
ns \\
$.2984^{*}$ \\
ns \\
\end{tabular} & $\begin{array}{l}\text { ns } \\
\text { ns } \\
\text { ns }\end{array}$ \\
\hline $\begin{array}{l}\text { RESPONSIBILITIES } \\
\text {.Marketing tasks } \\
\text {.Marketing research }\end{array}$ & \begin{tabular}{|l}
$.3328^{*}$ \\
$.6204^{*}$ \\
\end{tabular} & \begin{tabular}{|l|} 
ns \\
$.2804 *$ \\
\end{tabular} & $\begin{array}{l}\text { ns } \\
\text { ns } \\
\end{array}$ \\
\hline $\begin{array}{l}\text { TACTICS } \\
\text {.Tactics }\end{array}$ & $.4431^{*}$ & ns & $.3081^{*}$ \\
\hline
\end{tabular}

TABLE 11. Organizational Components-Correlation

\begin{tabular}{|c|c|c|c|c|c|c|}
\hline \multirow{3}{*}{$\begin{array}{l}\text { ORGANIZATION OF THE } \\
\text { DEPARTMENT OF MARKETING }\end{array}$} & \multicolumn{4}{|c|}{ RESPONSIBILITIES } & & \\
\hline & \multirow{2}{*}{$\frac{\text { Tasks }}{\text { BELGIUM }}$} & \multicolumn{3}{|c|}{ Marketing research } & \multicolumn{2}{|c|}{ TACTICS } \\
\hline & & SPAIN & BELGIUM & SPAIN & BELGIUM & SPAIN \\
\hline $\begin{array}{l}\text { - Specialization } \\
\text { - Years of departmenting } \\
\text { - Number of workers }\end{array}$ & $\begin{array}{l}\text { ns } \\
\text { ns } \\
.3873^{*}\end{array}$ & $\begin{array}{l}\mathrm{ns} \\
\mathrm{ns}\end{array}$ & $\begin{array}{l}.3320^{*} \\
\text { ns } \\
.5422^{* * *}\end{array}$ & $\begin{array}{l}\text { ns } \\
\text { ns } \\
4321^{*}\end{array}$ & $\begin{array}{l}\text { ns } \\
\text { ns } \\
.4759^{* * *}\end{array}$ & $\begin{array}{l}\text { ns } \\
3144^{*} \\
5942 * *\end{array}$ \\
\hline \multicolumn{7}{|l|}{ RESPONSIBILITIES } \\
\hline $\begin{array}{l}\text { Tasks } \\
\text { - Marketing research }\end{array}$ & ns & ns & & & $\begin{array}{l}.4737 * \\
.5324 * * *\end{array}$ & $\begin{array}{l}\text { ns } \\
7989^{*}\end{array}$ \\
\hline
\end{tabular}




\section{REFERENCES}

BAKER, M., BLACK, C. and HART, S.. 'The Competitiveness of British Industry: What Really Makes the Difference?', European Journal of Marketing, 22, 2, pp. 70-85, 1988.

BENNETT, R., and COOPER, R.. 'The Misuse of Marketing: An American Tragedy', Business Horizons, 24, January, pp. 51-61, 1981.

BOYD, H. and WALKER, O., Marketing Management: A Strategic approach. Homewood, Il: Richard Irwin, Inc., 1990

CRAVENS, D. Strategic Marketing, Richard Irwin, Illinois, Inc., 1987

EDGETT, S. and THWAITES, D. 'The Influence of Environmental Change on the Marketing Practices of Building Societies', European Journal of Marketing, 24, 12, pp. 35-47, 1990.

FERRELL, O. and LUCAS, G. 'An Evaluation of Progress in the Development of a Definition of Marketing', Journal of the Academy of Marketing Science, 15, Fall, $\mathrm{N}^{\circ} 3$, pp. 012-023, 1987.

GALLUCCI, C and RIVERA-CAMINO J., 'La implementación del concepto de marketing: un estudio empírico en empresas españolas', Documento de Trabajo 9702(01), Serie de Economía de la Empresa 05, Universidad Carlos III de Madrid., 1997.

GHOSH, B., SCHOCH, H., TAYLOR, D., KWAN, W., KIM, T..'Top performing organizations of Australia, New Zealand and Singapore: A comparative study of their marketing effectiveness', Marketing Intelligence \& Planning, 12, 7, pp. 39-48, 1994.

GREENLEY, G. and MATCHAM, A.. 'Marketing Orientation in the Service of Incoming Tourism', Marketing Intelligence \& Planning, 8, 2, pp. 35-39, 1990.

GREENWALD, J.."World Insurance Congress: Global Insurers Told to Put Clients Firths", Business Insurance, 25, 28, pp..3-4, 1992.

GRÖNROOS, C.. 'Designing a long range marketing strategy for services', Long Range Planning, 13 (2), April, pp. 36-42, 1980.

GRÖNROOS, C. 'Defining Marketing: A Market-Oriented Approach', European Journal of Marketing, 23, 1, pp. 52-60, 1989.

GUMMESSON, E. 'The marketing of professional services-25 propositions'. In Lovelock, C. (ed), Services Marketing, pp. 125-132, New Jersey: Prentice-Hall, 1984.

HAMPTON, G.. 'Have health care professionals adopted the marketing concept?', Health Marketing Quarterly, 10, 1, 2, pp. 5-32, 1992.

HAYES, R. and ABERNATHY, W. 'Managing our Way to Economic Decline', Harvard Business Review, 58 (July-August), pp. 67-77, 1980.

HOOLEY, G. and COWELL, D. 'The status of marketing in the UK service industries', Service Industries Journal, 5 (3), pp.261-272, 1985.

HOOLEY, G. and LYNCH, J. and SHEPHERD, J. 'The Marketing Concept: Putting the Theory into Practice', European Journal of Marketing, 24, 9, pp.7-24, 1990.

HOOLEY, G. and SAUNDERS, J. Competitive Positioning: The Key to Market Success, Prentice Hall, UK, 1993. 
HOOLEY,G. and HOOVER, D. 'Five Common Factors in Top Performing Industrial Firms', Industrial Marketing Management, 15, pp.89-96, 1986.

JAUCH, L. and GLUECK, W. Business Policy and Strategic Management, Mc Graw Hill, Fifth Edit, 1988.

JAWORSKI, B. and KHOLI, A. 'Market Orientation: Antecedents and Consequences', Journal of Marketing, 57 (July ), pp. 53-70, 1993.

KOTLER, P. Marketing Management: Analysis, Planning and Control, Prentice-Hall Englewood Cliffs, New Jersey, 1988.

LAMBIN, J. Strategic Marketing: A European Perspective, Mc Graw-Hill, London, 1993.

LOVELOCK, C. 'Why marketing management needs to be different for services'. In Donnelly, J. and George, W. (eds), Marketing of Services, American Marketing Association: Chicago, 1981.

MC CARTHY and PERREAULT W. (1990). Basic Marketing, IRWIN, 10th Edition.

MEINDL, J., HUNT, R., and LEE, W., (1989) Individualism-collectivism and work values: Data from the United States, China, Taiwan, Korea and Hong Kong. In A. Nedd, G-, Ferris, G. and Rowland K. (Eds), Research in Personnel and Human Resources Management, Supp.1. Greenwich, CT: JAI Press 1989

MILES, R. and SNOW, C. (1978). Organizational Strategy, Structure and Process, McGrawHill.

MORGAN, N. (1990), 'Professional accounting firms and marketing'. Service Industries Journal, 10 (3), July, pp.599-613.

MORGAN, N. and PIERCY, N. (1991). 'Barriers to Marketing Implementation in U.K. Professional Service Firms', Journal of Professional Services Marketing, 8, 1, pp. 95-113.

MORGAN, R. and MORGAN, N. (1991). 'An Exploratory Study of Market Orientation in the U.K.Consulting Engineering Profession', International Journal of Advertising, 10, 4, pp. 333347.

MUTH, M. (1993). 'Cambios estructurales en el sector asegurador europeo', Harvard DEUSTO Business Review, 5, pp. 78-89.

NUTTNEY A. (1995) "The marketing and Distribution of European Insurance" Datamonitor, Financial Times.

PIERCY, N. and MORGAN, N. (1989), 'Marketing organisation in the financial services sector', International Journal of Bank Marketing, 7 (4), pp. 3-11.

PIERCY, N. and ALEXANDER, N. (1988). 'The status quo of marketing organisation in UK retailing: a neglected phenomenon of the 1980s', Service Industries Journal, 8 (2), pp. 155176.

PORTER, M (1990)., The Competitive Advantage of Nations, New York: The Free Press.

Rapport de l'Office de Contrôle des Assurances: 1992-1993 (1994), Office de Contrôle des Assurances, Bruxelles.

SCOTT, W. MITCHELL, T. and BIRNBAUM, P. (1981). Organization Theory: a structural and behavioral analysis, Richard Irwin, Fourth Edition. 
SPEED, R. and SMITH, G. (1993). 'Customers, strategy and performance', International Journal of Bank Marketing, 11, 5, pp. 3-11.

THOMAS, M., (1994). 'Marketing - In chaos or transition?', European Journal of Marketing, 28,3 , pp. 55-62.

THWAITES, D. and LYNCH, J. (1992). 'Adoption of the Marketing Concept by UK Building Societies', Service Industries Journal, 12, 4, pp. 437-462.

Trends Top 5000 (1994), Financieel Ekonomisch Magazine, December.

WALKER, O. and RUEKERT R. (1987). 'Marketing's Role in the Implementation of Business Strategies: A critical Review and Conceptual Framework', Journal of Marketing, 51 (July), pp. 15-33.

WEBSTER, F. (1992). 'The Changing Role of Marketing in the Corporation', Journal of Marketing, 56, (October), pp. 1-17.

WEBSTER, F. (1994). 'Executing the new marketing concept', Marketing Management, 3, 1, pp. 8-16. 